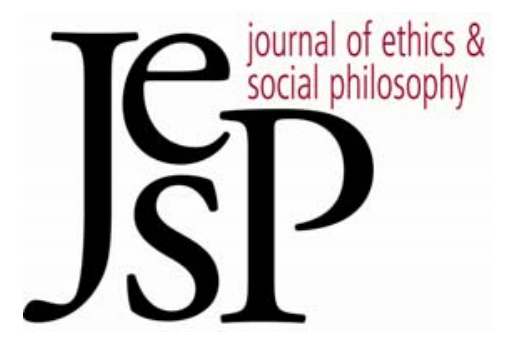

\title{
THE LIMITS OF DEMOCRATIC AUTHORITY
}

BY C.L. TEN

Journal of Ethics \& Social Philosophy

SYMPOSIUM I| AUGUST 2011

URL: WWW.JESP.ORG

COPYRIGHT (C) C.L. TEN 2011 


\title{
The Limits of Democratic Authority
}

\author{
C.L. Ten
}

$T$ HE CONSTITUTION OF EQUALITY PROBES the theoretical foundations of democracy in a detailed, systematic and very instructive manner. The arguments are nuanced and the conclusions challenging, ranging over many central issues in political theory. I shall focus on the book's account of the authority of democracy and the considerations which undermine or weaken its legitimate authority.

Christiano argues that the idea of public equality provides grounds for three things: (1) the democratic process, (2) the liberal rights of freedom of conscience, freedom of private pursuits, freedom of association and freedom of expression and (3) the guarantee of a certain economic minimum.

Democratic decision-making treats each citizen publicly as an equal in the face of pervasive disagreements about justice and the common good, and disagreements about the value of substantive laws and policies. A just system of laws must impose a unitary system on all, both those who agree and those who disagree with the system. These disagreements are about the shape of the common world in which all citizens live. In the common world there is a deep interdependence of fundamental interests among all citizens. They all have roughly equal stakes in shaping their shared world. Each should be given an equal say in how his or her political society is organized. Being disenfranchised, or having systematically less political power than others, would lead to, and will be seen to result in, a setback in the person's fundamental interests. These interests, which are protected by both the democratic process and liberal rights, are interests in truth, in correcting for cognitive bias, in being at home in the world - i.e. in having a sense of fit, connection and meaningfulness in our larger society - rather than just in various voluntary associations of our choice, and an interest in being recognized and affirmed as an equal.

Christiano thinks that some of these weighty interests are advanced by liberal rights in a world where people have different beliefs and interests. For example, each person has an interest in acquiring true beliefs through trial and error, and through the critical scrutiny of various ideas. The process of first formulating one's own beliefs, reflecting on them and receiving the responses of others to them, and similarly reflecting on and evaluating other beliefs develops one's capacities. The beliefs which people have about significant matters tend to be cognitively biased toward their own interests. So if one group is allowed to impose its beliefs on others, then it is likely that the group imposed upon will have its interests subordinated to those of the imposing group. If people do not have liberty of conscience to form their own beliefs, but are required instead to accept officially sanctioned beliefs, then they are unable to shape the world in which they live in accordance with their interests and perspectives, or to develop a conception of the world that is intelligible to them and engages with their interests and viewpoints. 
But liberal rights carry certain costs for others. Their exercise threatens people's interests in having intellectual and cultural homogeneity. Christiano argues that liberal rights meet many of the costs incurred by their exercise. For example, freedom of association and freedom to pursue private interests can provide some protection for the interests in cultural homogeneity by allowing people to create associations of like-minded persons, and to remain within them if they wish to avoid the company of others in the larger society who have different values and interests. Individuals can also exercise their freedom to exit from a group that they find oppressive, or to speak out against it. They can also to some extent choose whether to expose themselves to politically threatening and offensive ideas and practices of others. Again, the threat that the exercise of liberal rights might pose to justice and the security and material prosperity of society can often be checked by the public exercise of liberal and democratic rights. Freedom of conscience and religion is less likely to lead to civil strife than the attempt by some to use the power of the state to advance their particular religious and moral agendas by imposing them on others.

Each interest protected by a liberal right is more important than, and undefeated by, the interests opposed to it. But can the aggregate of the lesser interests of many people outweigh the interests protected by the liberal rights of one person? Christiano believes that the principle of public equality gives each person a fundamental and equal right to freedom of conscience and other liberal rights. Public equality requires that liberal rights are trumps, and that people's interests be compared in a pairwise manner, thereby ruling out the sacrifice of one person's interests for the less important aggregate interests of many persons. On a pairwise comparison, the weighty interests protected by the rights of one person always outweigh the interests of another person who is adversely affected by the exercise of the rights.

Christiano also maintains that an economic minimum is necessary for the successful exercise of liberal and democratic rights. One needs some basic means in order to advance one's fundamental interests.

Christiano believes that the democratic process is intrinsically fair, even though it can produce some unjust outcomes. Public equality is not the whole of justice. But the unjust outcomes of the democratic process originate from fair procedures, and they do not undermine the legitimacy of democratic authority. Democratic decision-making is a public and fair way of making collective decisions. Democratic equality takes precedence over other forms of equality because the most important duty of equality is to treat persons publicly as equals. So even if the democratic decision-making results in a mistaken conception of what equality requires in substantive legislation, citizens still have a duty to obey the wrong decision. Democratic procedures are valued because they embody public equality. The procedures and the outcomes are separate and independent in the sense that the substantively unjust outcomes, when they do not violate public equality, do not affect the basis for 
the choice of the procedures. Citizens have content-independent reasons for obeying democratic decisions. It is only by so doing that they can act justly.

But what are the limits of democratic authority? Christiano distinguishes between countervailing and undercutting considerations against democratic authority. Countervailing considerations are to be balanced against the weighty considerations for obeying democratic decisions, overriding them in some cases, but being outweighed by them in other cases. On the other hand, the undercutting considerations limit democratic authority by the fact that they involve considerations of the same kinds as those which support democratic authority. Thus democratic authority is grounded in public equality, as are liberal rights and a decent economic minimum. The authority of the democratic assembly is undercut if it undermines the core of liberal rights or the requirement for an economic minimum. However, Christiano does not seem to think that the scope or the basis of the undercutting of democratic authority is the same in the two cases.

His response to violations of liberal rights is clear. A democratic assembly has legitimate authority only when it publicly realizes justice in itself, or when it is instrumentally just. If it disenfranchises some part of the sane adult population, or suspends the core liberal rights of some, then it publicly violates equality. It thereby loses its legitimate authority. Its public violations of equality undercut its democratic authority. The assembly can no longer embody public equality when its actions clearly commit it to the rejection of public equality. The decision-making process of the democratic assembly is no longer just. The loss of democratic authority is localized to the particular piece of legislation that violates public equality. The disappearance of democratic authority with respect to a particular law does not, however, rule out instrumental or pragmatic reasons for still obeying the law, such as the adverse effect of disobedience on the general efficacy of the system of laws.

But Christiano is less clear about the effect on the authority of the democratic assembly when it fails to secure an economic minimum. He claims that its authority is "significantly weakened" and that the structure of the argument for the limit to its authority is the same as in the cases of liberal and democratic rights, but the nature of the limit is "a bit different" (p. 272). In his account, an economic minimum is not related to public equality in the same way as democratic and liberal rights. Whereas the violations of liberal and democratic rights are themselves direct violations of public equality, the failure to secure an economic minimum is not itself such a violation. Rather, it deprives people of the means for exercising their rights. Nor does Christiano believe that it is a limit to the authority of the democratic assembly if it does not provide people with equal means for realizing their rights. There are also various other means to the effective exercise of democratic and liberal rights, including the level of the citizen's education. Christiano does not discuss them, nor does he treat them on par with an economic minimum as considerations limiting democratic authority. Presumably this is because the 
failure to provide adequately a means for the exercise of a right is one step removed from the violation of the right and the interest it protects.

Given the above considerations, one would expect that the assembly's failure to secure an economic minimum for all its citizens does not undermine its authority in the same way as violations of democratic and liberal rights. But what exactly is the difference? Christiano suggests that one difference is the scope of the assembly's authority that is undermined. Democratic authority must satisfy both negative and positive requirements, and failure to do either undermines its authority. A democratic assembly violates the negative requirements when its legislation violates public equality. It violates the positive requirements when it fails to assure the economic minimum for its citizens. This failure, unlike the violation of a negative requirement, cannot be attributed to a particular piece of legislation. So the authority is not undermined just for a particular law. Rather, there is a general weakening of democratic authority. Christiano is unclear whether the general weakening of democratic authority applies to all citizens or only to those who are not assured the economic minimum. The general structure of the argument when applied to democratic and liberal rights suggests that the loss of authority is not confined just to the victims of the injustice. One would expect the same to apply with respect to the failure to secure an economic minimum.

Christiano identifies the victims for special mention when he claims that "those who are not even assured of a minimum or the protection of their liberal or democratic rights are not required to treat the democratic assembly as having as extensive a right to rule as the others" (p. 277). But if the injustice to the victims is clear, then it should concern all citizens, just as it does when there is a violation of liberal rights. In both cases the value of public equality is undermined by the democratic assembly which acts in the name of all citizens. As Christiano notes elsewhere, the just system of law must impose a unitary system on all. It refers to the same common world in which all citizens live, and in which there is a deep interdependence of their fundamental interests.

Christiano's differential treatment of violations of liberal rights, on the one hand, and the failure to provide for an economic minimum, on the other hand, seem to reflect a deeper problem for his account of democratic authority, which considers the choice of democratic procedures as separate and independent from whatever substantively unjust outcomes they might produce which do no violate the idea of public equality. In including an economic minimum, Christiano treats a failure to provide an effective means for exercising democratic and liberal rights as a violation of the requirement of public equality. As noted earlier, he does not include other means, such as a reasonably high level of education. But if we give these other means the same significance as an economic minimum for promoting public equality, then we would have to regard all failures by the democratic assembly to make adequate provision for the means for exercising democratic and liberal rights as limits on democratic authority. We would have to regard such failures as, in 
the relevant sense, also violations of public equality. This would considerably increase the range of substantively unjust outcomes which weaken democratic authority, and thereby remove the sharp separation between the value of democratic procedures and various substantial outcomes they produce.

Christiano's account of the persistent minority also shows how substantively unjust outcomes can weaken democratic authority. He distinguishes between different types of cases. In one type, the persistent minority is the product of majority tyranny. The majority violates the civil, political and economic rights of the minority. However, the more interesting case is what he calls "the case of the pure problem of persistent minorities." Here the minority rarely gets its way in the common world it shares with the majority, not because of the tyranny of the majority, but because the majority makes considered judgments about what is just and unjust on the basis of its own conceptions and perspectives, which differ from the minority's. According to him, the clearest cases of such persistent minorities are indigenous groups in some societies. In fact, however, there are more general and pervasive features of some societies which generate other persistent minorities. The absence of cross-cutting interests is crucial. As Christiano points out, where there are such cross-cutting interests, minorities who lose out on one issue can recombine with a different group on another issue to form a new majority. So minorities and majorities are relative to issues. But the circumstances for the existence of cross-cutting interests are undermined when most people in a society have a single, distinctive and all-pervasive set of interests which overrides all their other interests, or when people's dominant interests are all connected in a seamless web which divides them from others with a different set of interests. Religious, ethnic and economic interests sometimes combine in this way to divide people into groups with little or no common interests.

Christiano acknowledges in the case of the pure problem of persistent minorities that the democratic process, liberal rights and an economic minimum are not by themselves sufficient to sustain the authority of democracy. He opts in addition for some minimum outcome standard which maintains that "a group of people is being treated unjustly when its interests are not being satisfied above some threshold." (297) So the authority of democracy is further limited by the requirement that the outcomes produced by the democratic process should cross the threshold for every group in society. But Christiano points out that "the minimum outcome standard is not sufficient for the realization of public equality." (298) A dictatorship which meets the standard, but avoids democratic procedures in its decision-making, would clearly violate public equality in the way it treats people's interests above the minimum threshold.

The qualification to Christiano's view by the introduction of the minimum outcome standard is in fact quite considerable. He had earlier argued for the independence and separateness of democratic procedures and various outcomes. A democratic procedure that embodies public equality can be intrinsically fair or just even when its outcomes are substantially unjust, provid- 
ed these outcomes do not violate public equality. But now he concedes that even when the democratic process, liberal rights and an economic minimum are in place, democratic authority might still be undermined if the satisfaction of the interests of any group in society falls below the relevant threshold. Here it appears that a major injustice to a vulnerable group of persons can weaken democratic authority. Although he focuses on persistent minorities, they are not the only vulnerable group. It is the depth and/or the extent of the injustice suffered by a group which defines the threshold. Various groups could be vulnerable at different times. Thus migrants, trying desperately to get into a country, or to remain there when they have already arrived, may be subjected to very unjust treatment. Or certain groups of criminals could be the victims of systematically excessive punishments passed by a democratic assembly which accepts popular myths about criminal deserts or the effectiveness of long periods of imprisonment. In these cases grave injustices to specific groups can result if the usual democratic process is left unchecked. Why should these substantial injustices to vulnerable groups, other than persistent minorities, not undercut the authority of the democratic assembly?

In order to distinguish between the persistent minority and other vulnerable groups whose interests are also not satisfied above the threshold, Christiano would have to put very different weights on the different ways in which these interests are not satisfied. He could claim that the interests of the persistent minority are not satisfied because of the violation of public equality, whereas there is no similar violation of public equality in the failure to satisfy the interests of other vulnerable groups. But it would be implausible to attribute the plight of the persistent minority simply to the violation of public equality, when the real cause lies elsewhere, in the way interests happen to cluster in a particular set of circumstances. The circumstances which lead to the existence of a persistent minority might be quite accidental, and certainly not the result of any deliberate public policy designed to promote public inequality. Indeed, the persistent minority would enjoy the benefits of expressions of public equality through their participation in democratic procedures and the exercise of liberal rights on an equal basis with individual members of other groups when we make pairwise comparisons between them. The undermining of the overall interests of some vulnerable groups by the policies adopted by the democratic assembly might also be more severe than any adverse effect experienced by the persistent minority.

Christiano also discusses how the institutions of constitutional constraints and judicial review can help to police the limits of democratic authority. He is right that democratic authority is not necessarily best served by purely majoritarian procedures. Indeed, it might be important to safeguard certain core liberal rights by restricting the areas in which collective decisions are required. Thus it could be argued that the right of consenting homosexuals to engage in sexual practices should not be put to the decision of a democratic assembly, where it could be the subject of popular prejudices from a majority. The point has wider significance. For it is possible that there are 
various democratic procedures which each embody public equality. The choice between them should then depend on the extent to which each is likely to produce good substantive outcomes, or minimize grave injustices, such as those inflicted on persistent minorities. The preferred procedure adopted might depart radically from majoritarian procedures. Of course there are limits to what can be counted as democratic procedures. It would appear that there must be universal adult franchise and periodic and genuinely free elections to the democratic assembly. But this leaves many options, including an upper House of Parliament - partially elected, or even unelected, but with limited powers - or even versions of John Stuart Mill's idea of plural votes for some. These various non-majoritarian devices need not have as their rationale the ability to veto the decisions of the more popularly elected members of the democratic assembly. Rather, the devices are intended to widen the range of issues, arguments and points of view which are brought into the democratic assembly for deliberation. They are also intended to lift the level of public debate about contentious issues. It is an empirical and open question whether some such non-majoritarian devices would indeed lessen the substantive injustices which emerge from the democratic assembly. But if they do, then this would seem to speak in their favor.

Finally, we should consider one other interesting possibility. There are recent claims about the existence of illiberal democracies on the one hand, and liberal autocratic regimes on the other hand. ${ }^{1}$ Perhaps these comments are based on too narrow a conception of democracy, equating it with universal adult suffrage and periodic elections, and purely majoritarian procedures, unchecked by judicial review by unelected judges. Such an account of democracy is too narrow because, for example, in between elections, the elected government of the day could completely control and manipulate the processes of belief-formation, making it unlikely that it will lose any future freely conducted elections. But even with a richer notion of democracy, which adds to the idea of democracy the presence of a great deal of political freedom, there can still be a fracture between democratic rights and liberal rights. Christiano does not consider such a separation between the two types of rights. The situations he discusses have them both present together as expressions of public equality. But the separation is, on his account, a conceptual possibility and, if the comments mentioned above are correct, then it is also an empirical reality. It is also an empirical issue whether, at certain stages of a society's development, democratic procedures would be effective in producing an economic minimum for all. Is the authority of democracy totally eroded if it cannot deliver liberal rights and an economic minimum under certain circumstances? In Christiano's account, even when there is a fracture between democracy and liberal rights, their normative unity remains. Both are still grounded in the same conception of public equality. So for that rea-

${ }_{1}^{1}$ See Fareed Zakaria, The Future of Freedom: Illiberal Democracy at Home and Abroad, Norton, New York, 2003. 
son, if we value liberal rights, then we should also appreciate the intrinsic value of democracy. We should work toward more favorable conditions for democracy and liberal rights to be available together, or at least hope that developments in society will bring about the necessary changes. However, if the outcomes of all available democratic procedures continue to be very unjust - whether or not the injustices involve violations of public equality then we have good reason for not instituting a democratic assembly until more propitious circumstances should emerge. So give us democracy, but perhaps, not yet!

C.L. Ten

National University of Singapore

Department of Philosophy

phitencl@,nus.edu.sg 